\title{
Evidence of incipient speciation in Astyanax scabripinnis species complex (Teleostei: Characidae)
}

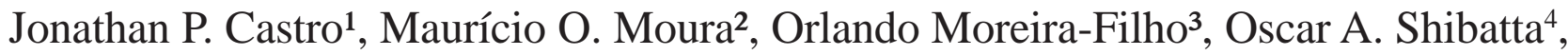 \\ Mateus H. Santos ${ }^{1}$, Viviane Nogaroto $^{1}$, Marcelo R. Vicari ${ }^{1}$, Mara C. de Almeida ${ }^{1}$, and \\ Roberto F. Artoni ${ }^{1}$
}

Two populations of the Astyanax scabripinnis complex, isolated by a waterfall with over 100 meters depth and inhabiting different altitudes of the same river (1850 $\mathrm{m}$ a.s.l. and $662 \mathrm{~m}$ a.s.l.) were compared in reproductive data, geometric morphometry, tooth morphology, anal-fin rays counts, and karyotype, in order to test the hypothesis of speciation between the two populations. The results in the geometric morphometry analysis showed differences between the populations. Discriminant function analysis (DFA) and canonical variance analysis revealed sexual dimorphism. Secondary sexual characters, such as hooks in the anal fin rays of the males are absent in the lower altitude population. Both populations had the same macro karyotype structure, except for the absence of B chromosomes in the lower altitude population. The fluorescence in situ hybridization showed differences for both markers (18S rDNA and 5S rDNA), and reproductive data suggests pre-zygotic reproductive isolation among the two populations. The data showed the absence of gene flow, indicating that an incipient speciation process has occurred, which leads the two populations to follow independent evolutionary pathways.

Duas populações do complexo Astyanax scabripinnis isoladas por uma queda d'água de mais de 100 metros de altura e localizadas em diferentes altitudes do mesmo rio (662 m e 1850 m a.s.l.) foram comparadas através de dados de reprodução, cariótipo, morfometria geométrica, morfologia dentária, e número de raios da nadadeira anal, de modo a testar a hipótese de especiação entre as duas populações. Os resultados de morfometria geométrica mostraram diferenças entre as populações. A análise da função discriminante (DFA) e a análise de variância canônica (CVA) demonstraram a presença de dimorfismo sexual. Caracteres sexuais secundários, como ganchos em raios da nadadeira anal dos machos, estão ausentes na população de menor altitude. Ambas as populações têm a mesma macro estrutura cariotípica, exceto pela ausência de cromossomos B na população de menor altitude. A hibridação in situ mostrou diferenças para ambos os marcadores (rDNA 18S e rDNA 5S), e os dados de reprodução sugerem isolamento reprodutivo pré-zigótico entre as duas populações. Os dados mostram ausência de fluxo gênico, indicando que ocorreu um processo de especiação incipiente, o que leva as duas populações seguirem vias evolutivas independentes.

Key words: Allopatric populations, Cytogenetics, Evolution, Geometric morphometry, Paraíba do Sul River.

\footnotetext{
${ }^{1}$ Departamento de Biologia Estrutural, Molecular e Genética, Programa de Pós Graduação em Biologia Evolutiva, Universidade Estadual de Ponta Grossa. Avenida Carlos Cavalcanti 4748, 84030-900 Ponta Grossa, PR, Brazil. jonathan.penacastro@gmail.com, vivianenogaroto@hotmail.com, vicarimr@yahoo.com.br, almeidamara@uol.com.br, rfartoni@uepg.br (corresponding author)

${ }^{2}$ Departamento de Zoologia, Universidade Federal do Paraná, Centro Politécnico. Avenida Coronel Francisco Heráclito dos Santos, 210, Jardim das Américas, 81531-980 Curitiba, PR, Brazil.mauricio.moura@ufpr.br

${ }^{3}$ Departamento de Genética e Evolução, Universidade Federal de São Carlos, Rodovia Washington Luis, Km 235, Monjolinho, 13565-905 São Carlos, SP, Brazil.omfilho@ufscar.br

${ }^{4}$ Departamento de Biologia Animal e Vegetal, Universidade Estadual de Londrina, Centro de Ciências Biológicas. Rodovia Celso Garcia Cid, Câmpus Universitário, 86051-970 Londrina, PR, Brazil. shibatta@uel.br
} 


\section{Introduction}

Allopatric populations possess intrinsic variability in morphological, genetic, and ontogenetic characters and this is the raw material that makes such populations important models for the study of evolutionary diversification (Badyaev et al., 2000).

Astyanax Baird \& Girard, 1854 belongs to a fish group that is widely distributed across Central and South America, representing one of the dominant taxa among the freshwater fishes of the region, with about 140 species distributed in practically every freshwater environment in the Neotropical region (Marinho \& Lima, 2009; Eschmeyer, 2013). This group is of particular interest in evolutionary studies aiming the elucidation of interrelations between species (Vicari et al., 2008a).

During his expedition to Rio de Janeiro, Charles Darwin collected a species of Astyanax "in a small ditch", which was described by Jenyns (1842) as A. scabripinnis. Within the genus, A. scabripinnis is recognized as a "species complex" based on its morphological and karyotypic variability (MoreiraFilho \& Bertollo, 1991). According to Bertaco \& Lucena (2006), species of this complex have "body deepest and heaviest in area proximate to middle of pectoral fins, head heavy, snout short and abrupt by tapering, body depth smaller than $41 \%$ of SL (13-23\%, usually $17-18 \%$, rarely 22 or $23 \%$ ), presence of one or two humeral spots, and a dark, midlateral, body stripe extending to the tip of the middle caudal-fin rays". Its populations are restricted to small streams or headwaters of small tributaries (Britski, 1972). Some populations have been isolated for millions of years in different hydrographic basins and are separated by hundreds of kilometers. Supernumerary chromosomes or B chromosomes have been recorded for 21 populations of the A. scabripinnis complex (Moreira-Filho et al., 2004).

Two populations of the $A$. aff. scabripinnis complex, isolated by a waterfall over 100 meters depth, located in the municipal region of Pindamonhangaba, Paraíba do Sul River, in the State of São Paulo, Brazil, in particular, possess characteristics that make the study of the evolution of the group interesting and representative. Both possess a very similar karyotype structure and are found in the same river, one group at an altitude of $1850 \mathrm{~m}$ a.s.l., restricted to the headwaters of the Ribeirão Grande River, and the other in sympatry with other species at an altitude of $662 \mathrm{~m}$ a.s.l.

The two populations were analyzed in the present study, using various markers and methodologies, with the objective of characterize these populations and test the hypothesis that their differences are produced by speciation, as well as to design an evolutionary scenario for their differentiation.

\section{Material and Methods}

\section{Sample Characterization}

Samples of 122 specimens of Astyanax aff. scabripinnis (Fig. 1) were collected on September 2010 from two popula- tions from the Mata Atlântica (Atlantic Forest) biome in the Ribeirão Grande River, at município de Pindamonhangaba, São Paulo, Brazil. Voucher specimens were catalogued in the Museu de Zoologia da Universidade Estadual de Londrina, Londrina: MZUEL 5655, 59 specimens, 60.7-83.9 mm SL (27 males and 32 females), 2248’24.60"S 45²6’55.80"W, 662 m a.s.l.; MZUEL 5656, 63 specimens, 46.0-81.0 mm SL (28 males and 35 females), $22^{\circ} 43^{\prime} 59.22^{\prime \prime S} 45^{\circ} 27^{\prime} 32.81^{\prime \prime W}, 1850 \mathrm{~m}$ a.s.l. All fishes were anesthetized using clove 110 oil (Griffiths et al., 2000), and euthanized before the assays, except for the samples of the reproductive analysis. The species was identified according to Melo (2001). All specimens were photographed for morphometric analysis, and parts of their internal tissues removed for cytogenetic and sexing confirmation before being sent to the deposit into a museum. Some intact specimens were also deposited for future morphological and taxonomic analyses. The source of the Ribeirão Grande River is found at an altitude of approximately $1940 \mathrm{~m}$ a.s.l., located in the município de Pindamonhangaba, in the State of São Paulo. Soon after its source, at an altitude of approximately 1800 m a.s.l., is the Santa Isabel Dam (Hydroelectric Power Plant) and below this point, the river descends steeply, reaching an altitude of $650 \mathrm{~m}$ a.s.l. Soon after this the river crosses a plain and its mouth is found on the left bank of the Paraíba do Sul River, at an altitude of approximately $400 \mathrm{~m}$ a.s.l.

The Ribeirão Grande is located on the plateau of Campos do Jordão, Serra da Mantiqueira, a mountainous region composed of crystalline rocks, southeastern Brazil and belongs to the basin of the Paraíba do Sul River. The landscape of southeastern Brazil is the result of Cenozoic tectonic processes that followed the Mesozoic-Cenozoic reactivation and opening of the basin of the South Atlantic Ocean (ModenesiGauttieri et al., 2002). However, it is possible to see changes in the landscape by tectonic activity occurred more recently during the Quaternary (Hiruma et al., 2001).

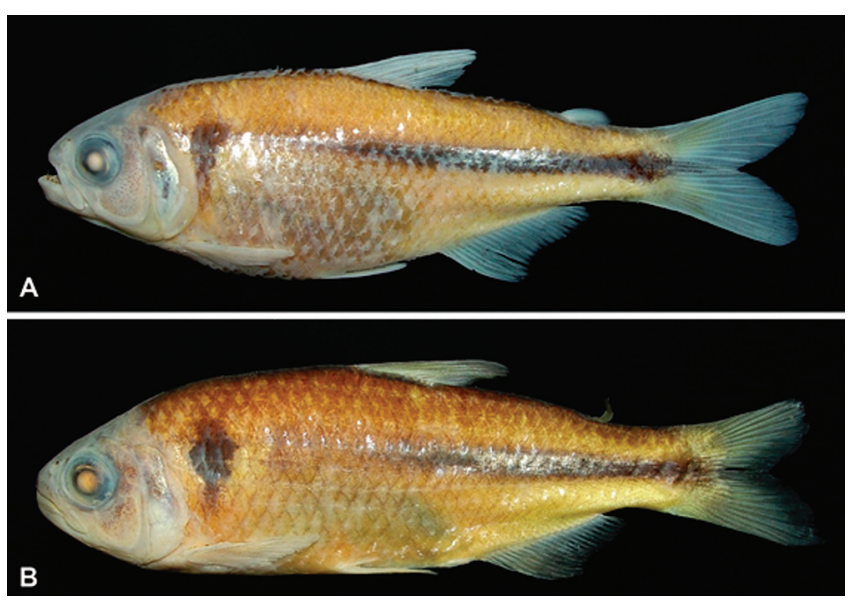

Fig. 1. Astyanax aff. scabripinnis. A - MZUEL 5656, 58,6mm CP, 1850 m a.s.l. B - MZUEL 5655, 83,5mm CP, 662 m a.s.l. Both from Ribeirão Grande, Pindamonhangaba, São Paulo, Brazil. 


\section{Geometric Morphometry}

Photos were taken using a Canon Powershot a495 camera, with resolution of 10 megapixels and at a standard focal distance of $30 \mathrm{~cm}$. TpsUtil 1.46 (Rohlf, 2010b) was used to group and format the data into a suitable file format (file extension *.tps). A total of 17 anatomic landmarks were selected (Fig. 2), representing the overall form of the body. Landmarks were digitized using tpsDig 2.16 (Rohlf, 2010a). To determine digitizing error, the process were repeated three times and analyzed using Anova (Hammer et al., 2001).

Next, Procrustes superimposition was carried out to eliminate variations in position, scale and orientation (Klingenberg, 2002), using Morpho J 1.02j (Klingenberg, 2011). This method superimposes all the individuals, centralizing and adjusting each configuration between homological marks, so that the deformation generated by differences in relation to the position of anatomic points is caused by shape variation. These deformations are known as partial deformations (Bookstein, 1991).

The differences in body shape between populations were determined using canonical variable analysis associated with multivariate variance analysis (MANOVA/CVA). Discriminant function analysis (DFA) was also performed to verify sexual dimorphism. All analyses were done in Morpho J 1.02j (Klingenberg, 2011).

\section{Morphological Analysis}

Ten specimens of each population were analyzed in relation to the number of teeth of the maxillary, the number of cusps on dentary teeth as well as reduction of the size of the teeth of the dentary. The numbers of unbranched and branched rays of anal fin were also counted.

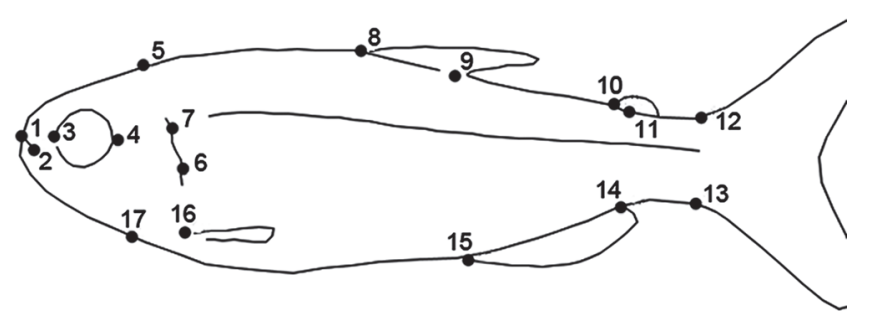

Fig. 2. Anatomical landmarks selected for morphometric analysis: 1:Snout tip; 2: Posterior region of premaxilla; 3: Anterior margin of eye; 4: Posterior margin of eye; 5: Dorsal region of head; 6: Lower curve of opercle; 7: Upper curve of opercle; 8: Anterior insertion of dorsal fin; 9: Posterior insertion of dorsal fin; 10: Anterior insertion of adipose fin; 11: Posterior insertion of adipose fin; 12: Dorsal beginning of caudal fin; 13: Ventral beginning of caudal fin; 14: Posterior insertion of anal fin; 15: Anterior insertion of anal fin; 16: Insertion of pectoral fin; 17: Ventral region of head.

\section{Scanning Electron Microscopy (SEM)}

SEM was performed to visualize the presence of hooks (secondary sexual characteristics) in the anal fins using whole specimens. The specimens were euthanized in deep anesthesia (Benzocaine 1\%) and immediately conserved in 70\% alcohol. Without special preparation, the pectoral and pelvic fins were submitted in natura to SEM analysis, under atmospheric pressure. The images were captured using increases between 300X and 2,000X, less than $15 \mathrm{kV}$ tension, with a Fei Quanta 250 scanning electron microscope.

\section{Reproduction}

After an acclimatization period of 24 hours in the laboratory, reproduction tests were undertaken to check if there is reproductive isolation between populations. The sex of the specimens was easily identified because males were expelling the sperm by simple pressure on the animal belly. A total of 24 tests of couples were performed. The specimens were kept in individual aquaria at a temperature of $26^{\circ} \mathrm{C}$ and were fed twice a day with ornamental fish feed. The couples were organized as follows: 1) 7 male vs. 7 female from Ribeirão Grande (662 m a.s.l.); 2) 7 males vs. 7 females from Ribeirão Grande (1850 m a.s.l.); 3$) 5$ males ( $662 \mathrm{~m}$ a.s.l.) vs. 5 females ( $1850 \mathrm{~m}$ a.s.l.) and 4) 5 males (1850 m a.s.l.) vs. 5 females (662 m a.s.l.), with the couples separated in individual aquaria in all cases. The choice of couples was performed randomly.

Seminatural induction was performed with an extract of carp pituitary diluted in $0.9 \%$ saline solution, in a concentration of $0.3 \mathrm{mg} / \mathrm{mL}$, in a single dose for male specimens, applied by intra peritoneal injection 12 hours after application in females. In female specimens, the hormone concentration used was $0.5 \mathrm{mg} / \mathrm{mL}$ (stock solution), applied in two doses: the first with the aim of finalizing the maturation of eggs with $10 \%$ of stock solution and the second inducing spawning with the full hormone solution. The time required for the reproduction process was about 24 hours. After spawning the parents were euthanized for cytogenetic and morphometric analysis.

\section{Cytogenetics}

The construction of the population idiogram was based on the standard karyotype described by Néo et al. (2000), using the Easy Idio 1.0 program (Diniz \& Melo, 2006). The locations of 18S rDNA and 5S rDNA in the idiogram were created in accordance with results obtained using fluorescence in situ hybridization (FISH) on mitotic chromosomes. The mitotic chromosomes were obtained using the technique described by Bertollo et al. (1978) and allowed the presence of $B$ chromosomes in the karyotype.

To identify $18 \mathrm{~S}$ and $5 \mathrm{~S}$ rDNA in the double FISH, an $18 \mathrm{~S}$ labeled probe was used, obtained from the nuclear DNA of the Prochilodus argenteus Agassiz, 1829 (Characiformes: Prochilodontidae) fish species (Hatanaka \& Galetti, 2004), using the NS1 5'-GTAGT CATATGCTTGTCTC-3' and NS8 5'-TCCGCAGGTTC ACCTACGGA-3' primers (White et al., 


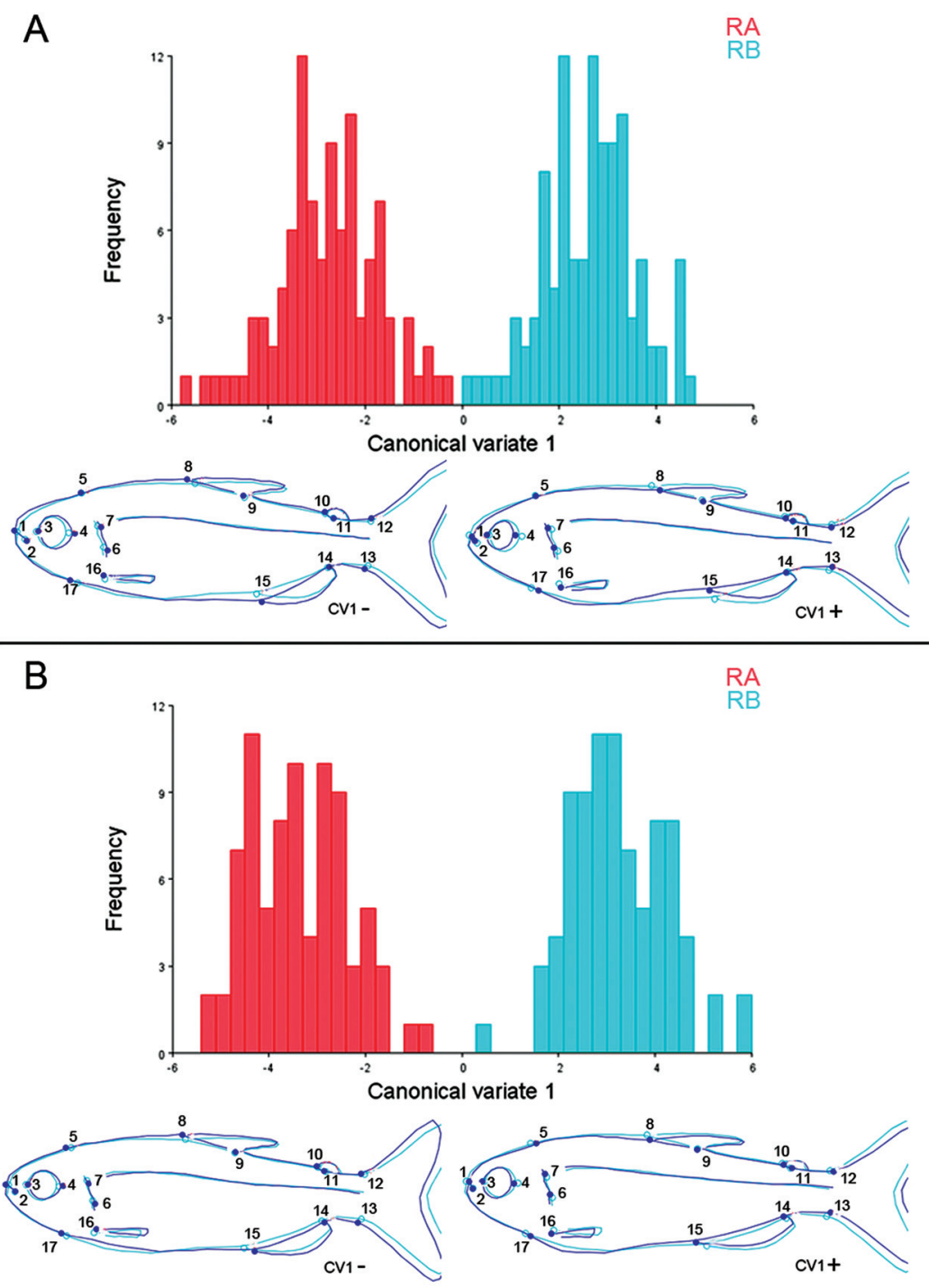

Fig. 3. Projection of Astyanax aff. scabripinnis individuals along the first two canonical axes. A: Projection of A. aff. scabripinnis females; B: Projection of A. aff. scabripinnis males. Shape deformations (dark line) for each CV axes are showed in relation to the reference configuration (light line). RA (red): Ribeirão Grande 662 m a.s.l.; RB (blue): Ribeirão Grande headwaters $1850 \mathrm{~m}$ a.s.l. Scale factor of fish drawing: 10.0 .

1990) and a 5 S probe, obtained using the 5'TACGCCCGATCTCGTCCGATC-3’ and B 5'GCTGGTATGGCCGTAGC-3’primers (Martins \& Galetti, 1999). The $18 \mathrm{~S}$ probe was labeled using the Biotin Nick Translation (Roche) kit, and the 5S kit was labeled using Dig Nick Translation (Roche) according to manufacturer instructions.

Hybridization was performed under highly stringent conditions (2.5 ng/iL probe, 50\% formamide, 2XSSC, 10\% dextrane sulfate), according to the general procedures described by Pinkel et al. (1986). Signal detection was performed with Streptavidin Alexa Fluor (Invitrogen) and Anti Digoxigenin Rodamine (Roche). The chromosomes were counterstained with DAPI $(0.2 \mathrm{ig} / \mathrm{mL})$ in Vectashield mounting medium (Vector), and analyzed with an Olympus BX41 epifluoresence microscope coupled to the DP 71 (Olympus) image capturing system.

\section{Results}

\section{Morphological analysis}

Measurement error analysis indicated that there were no errors in the allocation of landmarks (Wilks's lambda: 0.9058; $\mathrm{P}=0.9998$ ). The discriminant function analysis (DFA) showed that there was sexual dimorphism (Wilks's lambda $=0.4026$; df1 $=170 ; \mathrm{f}=1.95, \mathrm{P}<0.0001$ ), which therefore required separate morphometric analysis of males and females.

Female analysis indicated a clear separation between the populations (using the Mahalanobis and Procrustes 10,000 permutation test for distance between the groups, all with $\mathrm{P}<$ 0.0001 . Individuals from $1850 \mathrm{~m}$ a.s.l., corresponding to the positive first quadrant, revealed a shorter length of the anal fin base and dilation in the ventral region, near the pectoral fin (landmarks 15, 16, and 17). These individuals also had a 
thinner, flatter snout. The negative portion of the $1^{\text {st }}$ canonical axis shows the population from $662 \mathrm{~m}$ a.s.l. had greater length of the anal fin base, corresponding to points 14 and 15. The head region was more robust than in the other population (landmarks 1, 2, and 3). It was observed that specimens from this population had a more fusiform body (Fig. 3a).

The male analysis also indicated separation between populations, and a pattern of morphological variation similar to the female (using the Mahalanobis and Procrustes 10,000 permutations for distance test between the groups, all with $\mathrm{P}$ $<0.0001$ (Fig. 3b).

Astyanax aff. scabripinnis (from $1850 \mathrm{~m}$ a.s.l.) usually has a single tooth in the maxillary (80\%), or at most two. The teeth have up to five cusps and dentary teeth decreasing slightly in size until the fifth and abruptly from the sixth. Anal fin with iii, 16 (5), 17 (3), or 18 (2) branched rays.

Astyanax aff. scabripinnis (from $662 \mathrm{~m}$ a.s.l.) has two maxillary teeth (90\%), or at most three (no specimen had only one tooth). The tooth has seven cusps and dentary teeth decrease smoothly even after the fifth. Regarding the anal fin may occur iii-iv and 15 (1), 16 (3), 17 (2), 18 (2), or 19 (2) branched rays.

In addition, examination of the anal and pectoral fins of males showed significant difference between the Ribeirão Grande (662 m a.s.l.) and Ribeirão Grande (1850 m a.s.l.) populations. Males from the Ribeirão Grande (1850 m a.s.l.) population had hooks that were rugged to the touch, both in the pectoral fins and the anal fin. In contrast, the males of Ribeirão Grande (662 m a.s.l.) did not possess these structures (Fig. 4).

The two populations groups separate in the principal component analysis (Fig. 5), (Tables 1-2).

\section{Reproduction}

Reproduction tests found that only breeding between specimens from the same population produced offsprings. Specimens of 10 interpopulational crossbreeding experiments

Table 1. Weight of variables, eigenvalue and percentage of total variance of the first two axes of the principal component analysis. The second axis was subjected to shear procedure.

\begin{tabular}{lcc}
\hline \multicolumn{1}{c}{ Variables } & $\mathrm{CP} 1$ & $\mathrm{CP} 2(\mathrm{H})$ \\
\hline Standard length & 0.275132 & 0.032529 \\
Head length & 0.256103 & 0.107168 \\
Orbital diameter & 0.165607 & -0.261112 \\
Interorbital distance & 0.277893 & 0.377409 \\
Snout length & 0.274965 & 0.068421 \\
Upper jaw length & 0.249303 & 0.197602 \\
Predorsal distance & 0.276252 & 0.071457 \\
Dorsal-fin base length & 0.240875 & -0.388593 \\
Prepelvic distance & 0.284313 & -0.007042 \\
Anal-fin base length & 0.242559 & -0.224935 \\
Cauda peduncle depth & 0.290054 & 0.102983 \\
Pectoral-fin length & 0.286626 & -0.508846 \\
Pelvic-fin length & 0.266888 & -0.045308 \\
Anal-anal fin length & 0.177358 & 0.444845 \\
Dorsal-fin length & 0.270795 & -0.228869 \\
\hline Eigenvalue & 0.072 & 0.002 \\
\hline \% Total variance & $90.004 \%$ & $2.718 \%$ \\
\hline
\end{tabular}

did not spawn or release sperm, even with hormonal stimuli and in the same controlled environmental conditions in which the remaining breedings were performed.

\section{Cytogenetics}

Both populations shared a similar karyotype macrostructure, proven by their idiograms (Fig. 6a, b), with the diploid number $2 \mathrm{n}=50$ chromosomes, comprising two metacentric pairs, 11 submetacentric pairs, five subtelocentric pairs and six acrocentric pairs. Only the population from Ribeirão Grande (1850 m a.s.l.) possessed chromosome B, completely heterochromatic equivalent in the morphology (metacentric) and size to Pair 1 (Fig. 6a). In the population taken from a lower altitude (662 $\mathrm{m}$ a.s.l.) the presence of B chromosomes was not registered, corroborating the findings of Néo et al. (2000).

The analysis of the FISH pair in the two populations indicated a difference in the number and location of the sites of 18S rDNA and 5S rDNA (Fig. 7a, b). Four 18S rDNA sites were identified, in the distal region of the short arm of one submetacentric and one submetacentric pair in the Ribeirão Grande (1850 m a.s.l.) population (Fig. 7a), while six sites were located in the Ribeirão Grande (662 m a.s.l.) population, in one acrocentric pair and in two subtelocentric pairs (Fig. 7d).

Of the $5 \mathrm{~S}$ rDNA sites, six were located in the Ribeirão Grande (1850 m a.s.l.) population, in two acrocentric pairs and one metacentric pair (Fig. 7b), while for the Ribeirão Grande (662 m a.s.l.) population, eight sites were located, in subtelocentric and acrocentric pairs (Fig. 7e). There was no localization of $18 \mathrm{~S}$ or $5 \mathrm{~S}$ rDNA on chromosome B unique to the Ribeirão Grande (1850 m a.s.l.) population. Additionally, one of the chromosomes of Pair 22 of the Ribeirão Grande (662 $\mathrm{m}$ a.s.l.) population indicated in situ localization in synteny of $18 \mathrm{~S}$ rDNA and 5S rDNA (Fig. 7f).

Table 2. Morphometry of two populations of Astyanax aff. scabripinnis from Ribeirão Grande River, at município de Pindamonhangaba, São Paulo, Brazil, collected above (1850 $\mathrm{m}$ a.s.l.) and below a waterfall (662 $\mathrm{m}$ a.s.l.).

\begin{tabular}{lcccc}
\hline \multicolumn{1}{c}{ A. aff. scabripinnis } & \multicolumn{2}{c}{$(1850 \mathrm{~m})$} & \multicolumn{2}{c}{$(662 \mathrm{~m})$} \\
Morphometric variables & Range & Mean \pm SD & Range & Mean \pm SD \\
\hline Standard length (mm) & $46.0-81.7$ & $60.2 \pm 12.707$ & $60.7-83.9$ & $68.9 \pm 7.174$ \\
& Percents of standart length & & \\
Predorsal distance & $48.8-52.7$ & $50.9 \pm 1.118$ & $48.1-54.2$ & $50.5 \pm 1.622$ \\
Dorsal-fin base length & $11.7-14.9$ & $13.3 \pm 1.134$ & $12.0-16.0$ & $13.8 \pm 1.254$ \\
Prepelvic distance & $45.2-49.9$ & $47.8 \pm 1.376$ & $45.3-50.5$ & $48.4 \pm 1.573$ \\
Anal-fin base length & $20.0-25.2$ & $21.5 \pm 1.620$ & $19.4-23.7$ & $21.6 \pm 1.652$ \\
Cauda peduncle depth & $11.3-12.8$ & $11.8 \pm 0.482$ & $10.9-12.6$ & $11.7 \pm 0.497$ \\
Pectoral-fin length & $17.6-22.8$ & $19.3 \pm 1.504$ & $19.2-22.4$ & $21.1 \pm 1.010$ \\
Pelvic-fin length & $14.7-17.6$ & $15.6 \pm 0.968$ & $14.4-16.4$ & $15.5 \pm 0.605$ \\
Anal-anal fin length & $16.6-24.2$ & $18.4 \pm 2.342$ & $13.6-18.9$ & $16.5 \pm 1.447$ \\
Dorsal-fin length & $21.8-26.3$ & $23.8 \pm 1.419$ & $22.7-26.4$ & $24.7 \pm 1.269$ \\
Head length & $25.4-27.9$ & $26.4 \pm 0.837$ & $24.0-26.9$ & $25.5 \pm 0.991$ \\
& Percents of head length & & \\
Orbital diameter & $24.6-35.4$ & $31.1 \pm 3.360$ & $28.8-38.2$ & $31.7 \pm 2.682$ \\
Interorbital distance & $31.4-38.6$ & $34.6 \pm 2.200$ & $31.2-35.5$ & $33.4 \pm 1.332$ \\
Snout length & $25.3-33.2$ & $28.2 \pm 2.311$ & $26.7-30.0$ & $28.8 \pm 1.044$ \\
Upper jaw length & $42.3-47.3$ & $44.8 \pm 1.741$ & $41.8-46.1$ & $43.8 \pm 1.392$ \\
\hline
\end{tabular}




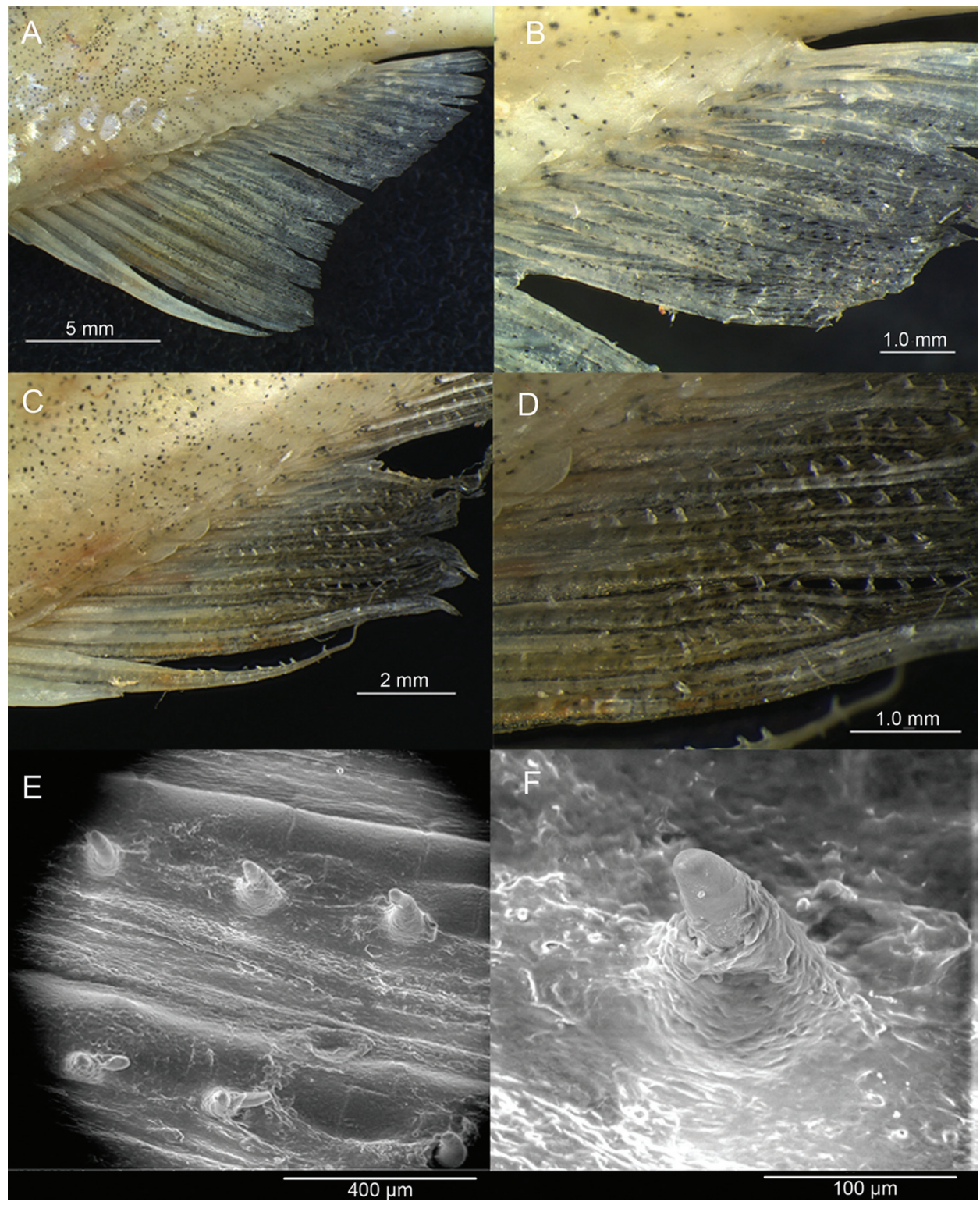

Fig. 4. Details for the anal fin of male of $A$. aff. scabripinnis with and without hooks. A: Anal fin of male from Ribeirão Grande (662 m a.s.l.); B: detail of fin without hooks; C: Anal fin of male from Ribeirão Grande (1850 m a.s.l.); D: detail of fin with hooks; $\mathbf{E}$ and $\mathbf{F}$ : Scanning electron micrography showing hook in detail.

\section{Discussion}

The results showed that the two populations of $A$. aff. scabripinnis studied were morphometrically differentiated, including in the presence or absence of sexual dimorphism. Morphometric differences may indicate individuals adapted to their distinct environments, as a result of the influence of selective pressures, which may in turn be reflected in genetic divergence (Swain \& Foote, 1999).

As found by Moreira-Filho \& Bertollo (1991), the morphological and chromosome variation identified in $A$. aff. scabripinnis populations, indicates that this is a species complex. Small, isolated populations suggest that these populations may be affected by genetic drift, following different evolutionary paths (Kavalco \& Moreira-Filho, 2003).
In A. aff. scabripinnis from Ribeirão Grande (1850 ma.s.l.) it was observed that the anterior region of the body was higher than the posterior, while the inverse was true in the population taken from lower altitude (662 $\mathrm{m}$ a.s.l.), where the posterior region of the body was higher. In this population (662 $\mathrm{m}$ a.s.l.), the general body form was more fusiform, suggesting a more effective hydrodynamic form against predators and in the search for food (Sibbing \& Nagelkerke, 2001). Supporting this observation, this environment has greater occurrence and predation of other species in sympatry with A. aff. scabripinnis, as highlighted by Néo et al. (2000), that may indicate selection effect in favor of the hidrodynamic shape body of the lower altitude.

The difference in the dentition, both in decreasing the size of the teeth of the dentary, as the number of cusps of the teeth, 


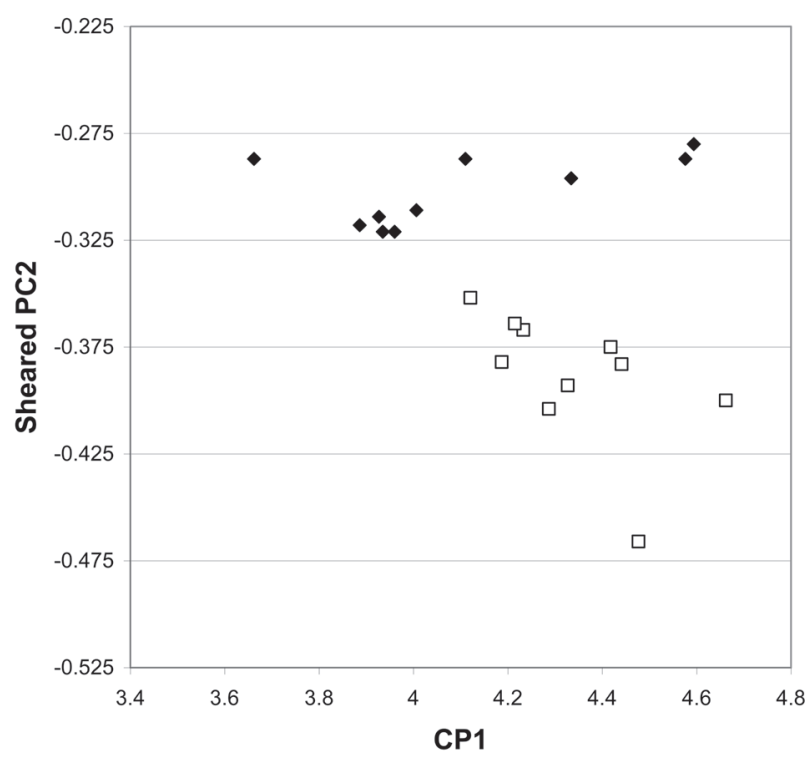

Fig. 5. Dispersion of individual scores in the first and second axes of principal component analysis with shear. Dark diamonds $=A$. aff. scabripinnis $(1850 \mathrm{~m})$; Clear square $=A$. aff. scabripinnis (662m).

may also be due to selective pressure, since they are related to the ability to capture food. Genera of Characidae has been identified by morphology and dental formula, but the observed variations are not necessarily related to the phylogeny (Weitzman \& Fink, 1983). Melo (2001) recognized six species of Astyanax for the basin of the Paraíba do Sul River, and A. intermedius Eigenmann, 1908 was previously considered as subspecies of A. scabripinnis. According to the author, A. intermedius has seven cusps on the teeth and the size of the dentary teeth decreasing abruptly from the fifth tooth. The population of the locality $662 \mathrm{~m}$ a.s.l. is similar in the number of tooth cusps, but differs by having the teeth decreasing slightly in size, even after the fifth tooth. Highlight is the fact that Melo (2001) have not observed the presence of $A$. scabripinnis in the basin, but our studies show that the population at $1850 \mathrm{~m}$ a.s.l. belongs to a species with morphological characteristics that make it close to $A$. scabripinnis, including the presence of hooks in the anal fin rays.

The presence of hooks on fins has been reported in various species of characins, including other Astyanax species (Andrade et al., 1984; Andrade et al., 2004; Porto-Foresti et al., 2005), and is considered a temporary secondary sexual characteristic which appears only in males, generally, during the reproductive period (Ihering \& Azevedo, 1936). According to Malabarba \& Weitzman (2003), the presence of hooks on fins in adult males is a synapomorphy of the clade that includes the Gasteropelecidae, Serrasalmidae, and Characidae, and Mirande (2010) considers the absence of hooks as being a plesiomorphic character. In the present study, both populations were collected during the reproductive period, in September 2010, but this characteristic was absent in males from the low altitude population and present only in the high

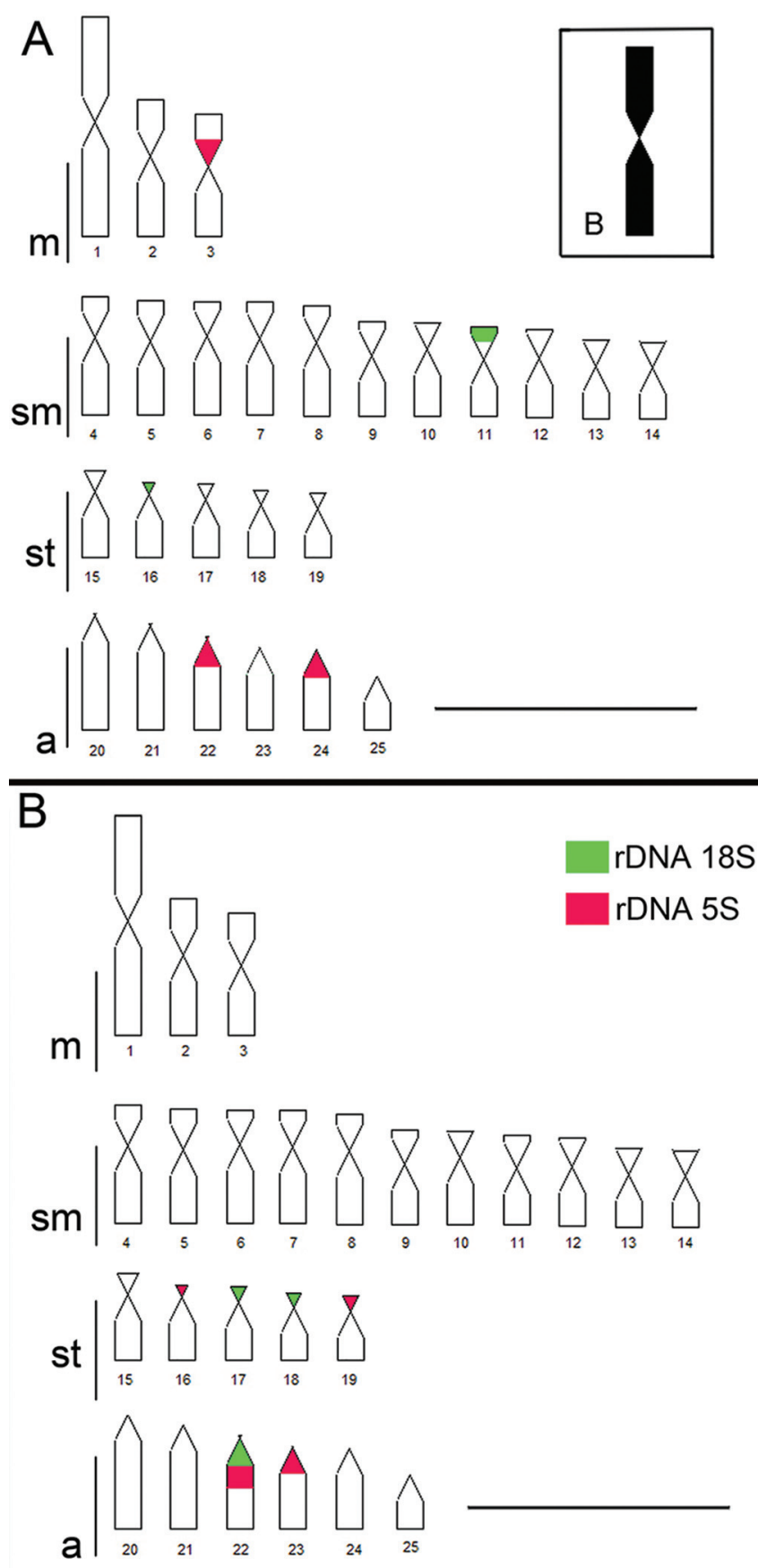

Fig. 6. Idiogram of populations of Ribeirão Grande $1850 \mathrm{~m}$ a.s.l. (A) and $662 \mathrm{~m}$ a.s.l. (B), based on karyotype of Néo et al. (2000). The interpretation of result obtained in FISH is illustrated, for $18 \mathrm{~S}$ and $5 \mathrm{~S}$ rDNA probes. Chromosome B observed in the Ribeirão Grande (1850 m a.s.l.) population was metacentrically large, and totally heterochromatic. Bar = $10 \mu \mathrm{m}$.

altitude population. Such conditions may be related to isolation and consequent an indicative of speciation in these populations, with the low altitude group revealing a derived condition for this character.

Additionally, data collected during testing of semi-natural 

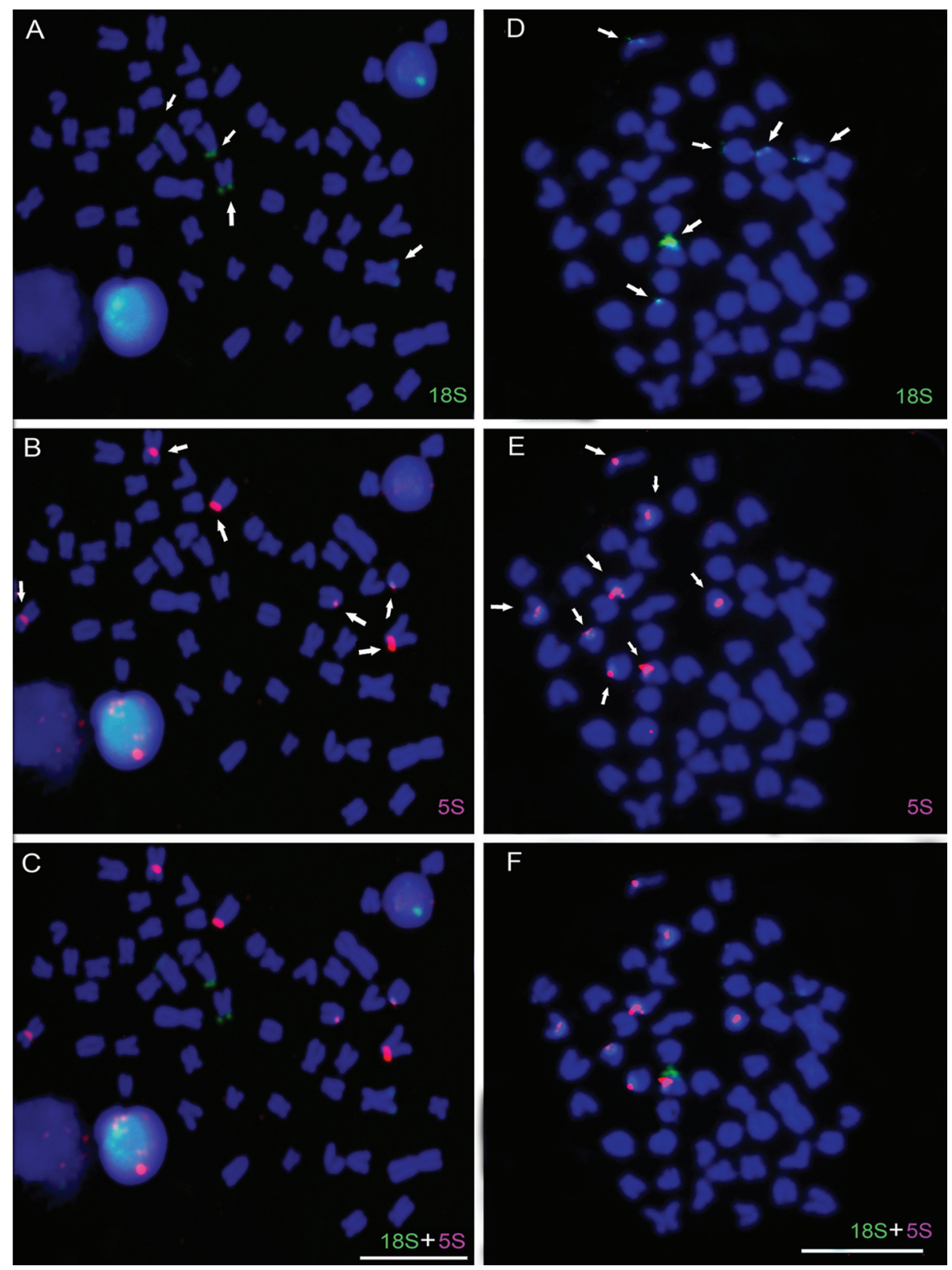

Fig. 7. Fluorescence in situ hybridization with $18 \mathrm{~S}$ rDNA (A and D) and $5 \mathrm{~S}$ rDNA (B and E) probes. Overlapping of images (C and F). Ribeirão Grande (1850 m a.s.l.), images (A-C); Ribeirão Grande (662 m a.s.l.), images (D-F). The arrow points indicate region of hybridization. $\mathrm{Bar}=10 \mu \mathrm{m}$.

reproduction suggests pre-zygotic reproductive isolation. Also, there was no evidence of gene flow between the populations indicating a case of allopatric speciation.

While possessing a conserved karyotype macrostructure, the populations studied possessed particular characteristics that permitted the identification at cytotaxonomic levels. The first notable characteristic is the exclusive presence of chromosome B in the higher altitude population, confirming the findings of Néo et al. (2000). Specific, more favorable, environmental conditions allowed greater tolerance for this extra genomic element in populations of $A$. scabripinnis at higher altitudes in the region of Campos do Jordão, in the
State of São Paulo, Brazil, explaining the presence or absence of this chromosome in different populations of $A$. scabripinnis.

Other cytogenetic markers were important in the comparative study of the populations analyzed. The number and location of the 18S rDNA sites in Astyanax is considered variable and multiple (Néo et al., 2000; Ferro et al., 2001; Mantovani et al., 2005 and Vicari et al., 2008a), dispersed by karyotypes mainly through transposition mechanisms (Fernandes \& Martins-Santos, 2006; Vicari et al., 2008b). The two populations from Ribeirão Grande analyzed in the present study corroborated with the condition of multiple 18S rDNA 
sites found in other Astyanax.

In relation to $5 \mathrm{~S}$ rDNA, this tended to be more conserved in Astyanax, being predominantly located in the proximal region of an acrocentric pair and a metacentric pair (Ferro et al., 2001; Almeida-Toledo et al., 2002; Mantovani et al., 2005; Vicari et al., 2008a). However, the occurrence of more chromosome pairs carrying this rDNA has been registered (Ferro et al., 2001; Vicari et al., 2011). The presence of eight $5 S$ rDNA sites in Astyanax, as verified in the present study in the Ribeirão Grande (662 m a.s.l.) population, indicates the highly derive condition of this population.

The synteny of 5S rDNA with 18S rDNA, as observed in the Ribeirão Grande (662 $\mathrm{m}$ a.s.l.) population, is suggested as a conserved condition for different fish groups (Jesus \& Moreira-Filho, 2003; Hatanaka \& Galetti, 2004; Vicari et al., 2006). Almeida-Toledo et al. (2002) observed similar details to the present study, with an 5S rDNA site co-localized with 28S rDNA in two acrocentric pairs, in a population of Astyanax paranae of the rio Tietê and in a population of $A$. aff. fasciatus (Cuvier, 1819) from the Mogi-Guaçu River, both in the State of São Paulo, Brazil. The authors inferred that the presence of moving elements of the transposon type in fish genomes was responsible for the different sites observed.

The diversification of number and chromosomal location of DNA ribosomal $18 \mathrm{~S}$ and $5 \mathrm{~S}$ sites were important cytotaxonomic markers in the populations analyzed, especially taking into account the environment in question. These may assume greater importance in identifying karyotypical geographic variations.

When all this data are analyzed together it can be inferred that the two populations represent distinct species, accumulating differences during a period of reproductive isolation, suggesting allopatric incipient speciation. However, the karyotype similarity of number and type of chromosomes, the exception of chromosome B and the differences observed in location of the ribosomal genes $18 \mathrm{~S}$ and $5 \mathrm{~S}$ among these "species", leads to a hypothesis of recent speciation.

The distribution of freshwater fishes in coastal basins was strongly influenced by various geological forces. A dynamic and continues movement explains the mixture of ichthyofauna between coastal and continental rivers, especially the capture of drainages and adjacent upland fauna (Ribeiro, 2006). This is the complex scenario in which it is installed and diversified A. scabripinnis in drainages of the Paraíba do Sul and those streams that flow into the Ribeirão Grande basin, located across the watershed (Serra da Mantiqueira).

Although we cannot determine the evolutionary scenario that lead to the differentiation between these two populations we can, however, to suggest that they do not belong to the same species. As a side effect, these results prompt a taxonomic review to determine the evolutionary units in these species complex. Also, our results highlight the use of multiple markers as a fundamental framework to uncover diversity patterns in cryptic species complex.

\section{Acknowledgments}

The authors are grateful to the Instituto Brasileiro do Meio Ambiente e dos Recursos Naturais Renováveis (IBAMA). This study was financed by the Fundação de Amparo à Pesquisa do Estado de São Paulo (FAPESP), Conselho Nacional de Desenvolvimento Científico e Tecnológico (CNPq) Coordenação de Aperfeiçoamento de Pessoal de Nível Superior (CAPES) and the Fundação Araucária (Fundação Araucária de Apoio ao Desenvolvimento Científico e Tecnológico do Estado do Paraná). To L. B. R. Fernandes for SEM techical supply (INCT Hympar-UFSCar).

\section{Literature Cited}

Almeida-Toledo, L. F., C. Ozouf-Costaz, F. Foresti, C. Bonillo, F. Porto-Foresti \& M. F. Z. Daniel-Silva. 2002. Conservation of the $5 \mathrm{~S}$ bearing chromosome pair and co-localization with major rDNA clusters in five species of Astyanax (Pisces, Characidae). Cytogenetics and Genome Research, 97: 229-233.

Andrade, D. R., A. L. Godinho, H. P. Godinho \& E. Shimoda. 2004. Biologia reprodutiva da tabarana Salminus hilarii (Osteichthyes, Characidae) na represa de Três Marias. Revista Brasileira de Ciência Veterinária, 11: 123-128.

Andrade, D. R., E. Menin \& S. P. Ribeiro. 1984. Periodicidade da característica sexual secundária em Astyanax bimaculatus (Linnaeus, 1758) Pisces, Characidae. Revista Seiva, 44: 9-12.

Badyaev, A. V., G. E. Hill, A. M. Stoehr, P. M. Nolan \& K. J. McGraw. 2000. The evolution of sexual size dimorphism in the house finch. II. Population divergence in relation to local selection. Evolution, 54: 2134-2144.

Bertaco, V. A. \& C. A. S. Lucena. 2006. Two new species of Astyanax (Ostariophysi: Characiformes: Characidae) from eastern Brazil, with a synopsis of the Astyanax scabripinnis species complex. Neotropical Ichthyology, 4: 53-60.

Bertollo, L. A. C., C. S. E. Takahashi \& O. Moreira-Filho. 1978. Cytotaxonomic considerations on Hoplias lacerdae (Pisces, Erythrinidae). Brazilian Journal Genetics, 1: 103-120.

Britski, H. A. 1972. Peixes de água doce do estado de São Paulo: sistemática, Pp. 79-180. In: Branco, S. M. (Org.). Poluição e Piscicultura. São Paulo, Faculdade de Saúde Pública da USP, Instituto de Pesca.

Bookstein, F. L. 1991. Morphometric Tools for Landmark Data: Geometry and Biology. Cambridge University Press.

Diniz, D. \& P. X. Melo. 2006. Easy Idio, version 1.0.

Eschmeyer, W. N. (Ed). 2013. Catalog of Fishes. California Academy of Sciences. Available from: http://research.calacademy.org/ research/ichthyology/catalog/fishcatmain.asp. (09 Jul 2013.)

Fernandes, C. A. \& I. C. Martins-Santos. 2006. Mapping of the $18 \mathrm{~S}$ and 5S ribosomal RNA genes in Astyanax altiparanae Garutti \& Britski, 2000 (Teleostei, Characidae) from the upper Paraná River basin. Brazilian Journal of Genetics and Molecular Biology, 29: 464-468.

Ferro, D. A. M., D. M. Néo, O. Moreira-Filho \& L. A. C. Bertollo. 2001. Nucleolar organizing regions, $18 \mathrm{~S}$ and $5 \mathrm{~S}$ in Astyanax scabripinnis (Pisces, Characidae): population distribution and functional diversity. Genetica, 110: 55-62.

Griffiths, S. P. 2000. The use of clove oil as an anaesthetic and method for sampling intertidal rockpool fishes. Journal of Fish Biology, 57: $1453-1464$. 
Hammer, Ø., D. A. T. Harper \& P. D. Ryan. 2001. PAST: Paleontological Statistics Software Package for Education and Data Analysis. Palaeontologia Electronica 4: 1-9.

Hatanaka, T. \& P. M. Jr. Galetti. 2004. Mapping of the 18 S and 5S ribosomal RNA genes in the fish Prochilodus argenteus Agassiz, 1829 (Characiformes, Prochilodontidae). Genetica, 122: 239-244.

Hiruma, S. T., C. Riccomini \& C. Modenesi-Gauttieri. 2001. Neotectônica no planalto de Campos do Jordão, SP. Revista Brasileira de Geociências 31: 375-384.

Ihering, R. V. \& P. Azevedo 1936. As piabas dos açudes nordestinos (Characidae, Tetragonopterinae). Archivos do Instituto de Biologia, 7: 75-110.

Jesus, C. M. \& O. Moreira-Filho. 2003. Chromosomal location 5S and 18S rRNA genes in Prochilodus lineatus (Characiformes, Prochilodontidae). Caryologia, 56: 281-287.

Jenyns, L. 1842. Fish. The Zoology of the voyage of H.M.S. Beagle, under the command of captain Fitzroy, R. N. during the years 1832 to 1836. London: Smith, Elder and Co.

Kavalco, K. F. \& O. Moreira-Filho. 2003. Cytogenetical analyses in four species of the genus Astyanax (Pisces, Characidae) from Paraíba do Sul River Basin. Caryologia, 56: 453-461.

Klingenberg, C. P. 2002. Morphometrics and the role of the phenotype in studies of the evolution of developmental mechanisms. Gene, 287: 3-10.

Klingenberg, C. P. 2011. MorphoJ: an integrated software package for geometric morphometrics. Molecular Ecology Resources, 11: 353-357.

Malabarba, L. R. \& S. H. Weitzman. 2003. Description of a new genus with six species from southern Brazil, Uruguay and Argentina, with discussion of a putative characid clade (Teleostei: Characiformes: Characidae). Comunicações do Museu de Ciências e Tecnologia da PUCRS, Série Zoologia, 16: 67-151.

Mantovani, M., L. D. S. Abel \& O. Moreira-Filho. 2005. Conserved $5 S$ and variable $45 \mathrm{~S}$ rDNA chromosomal localization revealed by FISH in Astyanax scabripinnis (Pisces, Characidae). Genetica, 123: 211-216.

Marinho, M. M. F. \& F. C. T. Lima. 2009. Astyanax ajuricaba: a new species from the Amazon basin in Brasil (Characiformes: Characidae). Neotropical Ichthyology, 7: 169-174.

Martins, C. \& P. M. Galetti. 1999. Chromosomal localization of 5S DNA genes in Leporinus fish (Anostomidae, Characiformes). Chromosome Research, 7: 363-367.

Melo, F. A. G. 2001. Revisão taxonômica das espécies do gênero Astyanax Baird e Girard, 1854, (Teleostei: Characiformes: Characidae) da região da serra dos Órgãos. Arquivos do Museu Nacional, 59: 1-46.

Mendes, M. M., R. Rosa, L. Giuliano-Caetano \& A. L. Dias. 2011. Karyotype diversity of four species of the incertae sedis group (Characidae) from different hydrographic basins: analysis of AgNORs, CMA3 and 18S rDNA. Genetics and Molecular Research, 10: 3596-3608.

Mirande, J. M. 2010. Phylogeny of the family Characidae (Teleostei: Characiformes): from characters to taxonomy. Neotropical Ichthyology, 8: 385-568.

Modenesi-Gauttieri, M. C., S. T. Hiruma \& C. Riccomini. 2002. Morphotectonics of a high plateau on the northewestern flank of the Continental Rift of Southern Brazil. Geomorphology, 43: 257-271.

Moreira-Filho, O. \& L. A. C. Bertollo. 1991. Astyanax scabripinnis (Pisces, Characidae): A species complex. Brazilian Journal of Genetics, 14: 331-357.

Moreira-Filho, O., P. M. Jr. Galetti \& L. A. C. Bertollo. 2004. B chromosomes in the fish Astyanax scabripinnis (Characidae,
Tetragonopterinae): An overview in natural populations. Cytogenetic Genome Research, 106: 230-234.

Néo, D. M., O. Moreira-Filho \& J. P. M. Camacho. 2000. Altitudinal variation for B chromosome frequency in the fish Astyanax scabripinnis. Heredity, 85: 136-141.

Pinkel, D., T. Straume, J. W. Gray. 1986. Cytogenetic analysis using quantitative, highsensitivity, fluorescence hybridization. Proceedings of the National Academy of Sciences USA, 83: 29342938.

Porto-Foresti, F., R. B. Castilho-Almeida \& F. Foresti. 2005. Biologia e criação do lambari-do-rabo-amarelo (Astyanax altiparanae), Pp.105-120. In: Baldisserotto, B. \& L. C. Gomes (Eds.). Espécies Nativas para Piscicultura no Brasil. Santa Maria: Ed UFMS.

Ribeiro, A. C. 2006. Tectonic history and the biogeography of the freshwater fishes from the coastal drainages of eastern Brazil: an example of faunal evolution associated with a divergent continental margin. Neotropical Ichthyology, 4: 225-246.

Rohlf, F. J. 2010a. tpsDig, Version 2.16. Department of Ecology and Evolution, State University of New York, Stony Brook. Available from: http://life.bio.sunysb.edu/morph/ (09 Jul 2013).

Rohlf, F. J. 2010b. tpsUtil, version 1.46. Department of Ecology and Evolution, State University of New York, Stony Brook. Available from: http://life.bio.sunysb.edu/morph/ (09 Jul 2013).

Sibbing, F. A. \& L. A. J. Nagelkerke. 2001. Resource partitioning by Lake Tana barbs predicted from fish morphometrics and prey characteristics. Reviews in Fish Biology and Fisheries, 10: 393437.

Swain, D. P. \& C. J. Foote. 1999. Stocks and chameleons: the use of phenotypic variation in stock identification. Fisheries Research, 43: $113-128$.

Travassos, H. \& R. S. Santos. 1955. Caracídeos fósseis da bacia do Paraíba. Anais da Academia Brasileira de Ciências, 27: 297-322.

Vicari, M. R., M. C. Almeida, L. A. C. Bertollo, O. Moreira-Filho \& R. F. Artoni. 2006. Cytogenetic analysis and chromosomal characteristics of the polymorphic 18S rRDNA in the fish Prochilodus lineatus (Characiformes, Prochilodontidae). Genetics and Molecular Biology, 29: 621-625.

Vicari, M. R., R. B. Noleto, R. F. Artoni, O. Moreira-Filho \& L. A. C. Bertollo. 2008a. Comparative cytogenetics among species of the Astyanax scabripinnis complex. Evolutionary and biogeographical inferences. Genetics and Molecular Biology, 31: 173-179.

Vicari, M. R., R. F. Artoni, O. Moreira-Filho \& L. A. C. Bertollo. 2008b. Colocalization of repetitive DNAs and silencing of major rRNA genes. A case report of the fish Astyanax janeiroensis. Cytogenetics and Genome Research, 122: 67-72.

Vicari, M. R., H. F. M. Pistune, J. P. Castro, M. C. Almeida, L. A. C. Bertollo, O. Moreira-Filho, J. P. M. Camacho \& R. F. Artoni. 2011. New insights on the origin of B chromosomes in Astyanax scabripinnis obtained by chromosome painting and FISH Genetica, 139: 1073-1081.

Weitzman, S. H. \& W. L. Fink. 1983. Relationships of the neon tetras, a group of South American freshwater fishes (Teleostei, Characidae), with comments on the phylogeny of new world characiforms. Bulletin of the Museum of Comparative Zoology, 150: 339-395.

White, T. J., T. Bruns, S. Lee \& J.W. Taylor. 1990. Amplification and direct sequencing of fungal ribosomal RNA genes for phylogenetics. Pp. 315-322. In: Innis, M. A., D. H. Gelfand, J. J. Sninsky \& T. J. White (Eds.). PCR protocols: a guide to methods and applications. New York, N.Y: Academic Press, Inc.

Submitted August 6, 2013

Accepted January 20, 2014 by Claudio Oliveira Published June 30, 2014 